\title{
CHIEF EDITOR'S NOTE ON NOTARIES IN THE BRICS COUNTRIES
}

\author{
DMITRY MALESHIN, \\ Lomonosov Moscow State University (Moscow, Russia)
}

DOI: $10.21684 / 2412-2343-2017-4-3-4-5$

Recommended citation: Dmitry Maleshin, Chief Editor's Note on Notaries in the BRICS Countries, 4(3) BRICS Law Journal 4-5 (2017).

The Notary plays an important role in the legal systems of many countries. The profession has a long history, for the first notaries are known from Roman times, and their prototypes extend even further back in time to Babylon and Egypt.

There are two different main types of notary in our modern times: the Latin type and the type found in the common law system. The Latin type of notary is usually found in the countries with a civil law system. The main difference between the two types concerns the role of the notary in jurisprudence and the competences the notary has. Civil law notaries have huge competence in different areas of jurisprudence, while common law notaries are limited in competence and notarize, that is, attest to as an impartial witness, signatures and copies of documents.

In the BRICS countries, notaries come in both types. In Brazil, Russia and China they are members of the International Union of Latin Notaries, whereas in South Africa and India they act within their capacities according to the common law system.

In Brazil, the notary is supervised by the National Council of Justice. The local judiciary is also responsible with regard to the activities of notaries. It adopts the local rules for the notaries and organizes examinations to enroll them in the profession. There are around 20,000 notaries in Brazil. At least one notary office should be organized in each local region.

There are six different categories of notaries in Brazil: (1) notary of individuals registration; (2) notary of real estate registration; (3) notary of documents registration; (4) notary of legal entities registration; (5) notary of maritime registration; and (6) notary of notes. The competence of notaries in Brazil is extensive. They register 
births, marriages, deaths, emancipation in respect of civil rights, adoptions, all real estate transactions and much more.

The Russian notary is also a member of the International Union of Latin Notaries (since 1995). This was a big reform in 1993 when the new Act on Notary was passed. The main goal of the reform was to establish the system of private notaries. And it was very successful: in just a few years almost all public notaries were replaced by private notaries. There are around 8,000 notaries in Russia today and only twenty-five of them are public notaries. What is more, 85 percent of Russian notaries are women.

One of the main characteristics of the Latin type of notary is the active role of the notary in real estate transactions. In fact, in 1993 Russian law stipulated that all real estate transactions need to have notarial authorization; however, this requirement was cancelled in 1995. At the present time, only a few kinds of real estate transactions need to have notarial authorization, among them such transactions involving juveniles.

All notaries in Russia must have a law degree, pass a special examination and be nominated as a notary by the Ministry of Justice. The notary may be regulated by both federal and local laws of the states of Russia. The most popular notarial acts sought are the copy of documents notarization - around 42 million per year (55\% of all notarial acts); signature notarization - 13 million (15\%); and power of attorney notarization - 11 million (15\%).

India is not a member of the International Union of Latin Notaries. Indian notaries are regulated by the Notaries Act of 1952 and the Notaries Rules of 1953. Appointment as a notary is the function of the government. Only legal practitioners with seven to ten years of experience may apply.

The notary profession in China is regulated by the Law on Notary of 2005. Notaries are supervised by the Ministry of Justice. There are around 12,000 notaries in the country. All the notaries are expected to work in a notary office that has been approved by local authorities. There are around 3,000 notary offices in China. The competences of the Chinese notary are similar to those of all the Latin type countries: notarization of real estate contracts; notarization of birth, death, marriage, divorce, adoption of children, etc.

South Africa has the common law system of notary. Only persons who have been recognized as an attorney by the Law Society of South Africa can apply to be a notary. Additionally, applicants must pass a notarial examination prepared by the Law Society of South Africa. The competences of the South African notary include: administering oaths and affirmations; taking affidavits and the notarization of copies of document and signatures. 